\title{
1. Rebalancing the Chinese Economy to Sustain Long-Term Growth
}

Huw McKay and Ligang Song

\begin{abstract}
Meeting the challenge of the domestic restructuring to sustain growth, asserting the right to develop and not to be penalized purely for being large, while taking on increased responsibility for global balance, stability, and governance and representing the interests of less-powerful developing countries are major new mountains to climb. China's success or failure will, in any event, have a significant impact on the rest of the world.
\end{abstract}

—Michael Spence (2011:198)

\section{Introduction}

The call to rebalance economic growth in China is primarily motivated by the structural problems within China as well as in its economic relations with the rest of the world. China's international payments surpluses during the first decade of the twenty-first century have corresponded with deepening domestic structural risks to China's economic growth and development. These structural challenges include the composition of growth resulting from China's dynamic internal transformation, China's trade orientation, the trajectory of resource use and carbon dioxide emissions, welfare problems of distribution and international constraints. It is thought to be necessary for China to confront these challenges now in order to put the growth path into a more sustainable trajectory in the future (Deer and Song 2012). The purpose of this year's China Update book is to examine the challenges China faces in addressing its economic imbalances and sustaining growth against a backdrop of heightened domestic and international uncertainty.

The transition from a traditional to a modern economic system entails major and often rapid structural change in economy-wide processes of industrialisation, urbanisation and agricultural transformation (Syrquin 1988). As a result of rapid structural change, transitional economic challenges arise, which can pose risks to future growth if not well managed. Rapid change can also create welfare challenges, as the institutional settings required for an equitable distribution 
of income might not be present. As such, the pursuit of 'balanced' economic growth is best thought of as a broad policy objective that aims to limit risks to growth and to mitigate the negative impact on welfare. It should therefore not be expressed as a particular target, such as a reduction in the current account surplus or a rise in the labour share of income. The role of policy should be to design and implement a framework that reduces distortions, encourages and rewards innovation, equalises access to education, employment, a social safety net and capital for investment, while minimising rent-seeking opportunities. The desire to achieve such an environment will create demand for institutional reforms that can facilitate these processes of structural change in the least disruptive fashion.

The enormous scale of China's aggregate imbalances - crudely summarised as the unbalanced nature of domestic expenditure - and its external payment surplus, which reflects a stark excess of saving over investment, are well known. Unbalanced domestic expenditure refers to China's high, and until recently, growing share of investment relative to consumption in the expenditure measure of gross domestic product (GDP). The external payment imbalance refers to China's current account, trade account and private financial account surpluses. While the list of Chinese economic characteristics that deserve the label 'unbalanced' is legion-including the level of the exchange rate, the urban-rural income divide, the coast-hinterland divide and asymmetries in the degree access to credit, education, social security and housing - at some level they all relate to and inform the basic macroeconomic structure and the external payments position.

Figure 1.1 China: Expenditure shares of GDP, 1978-2010 (per cent)

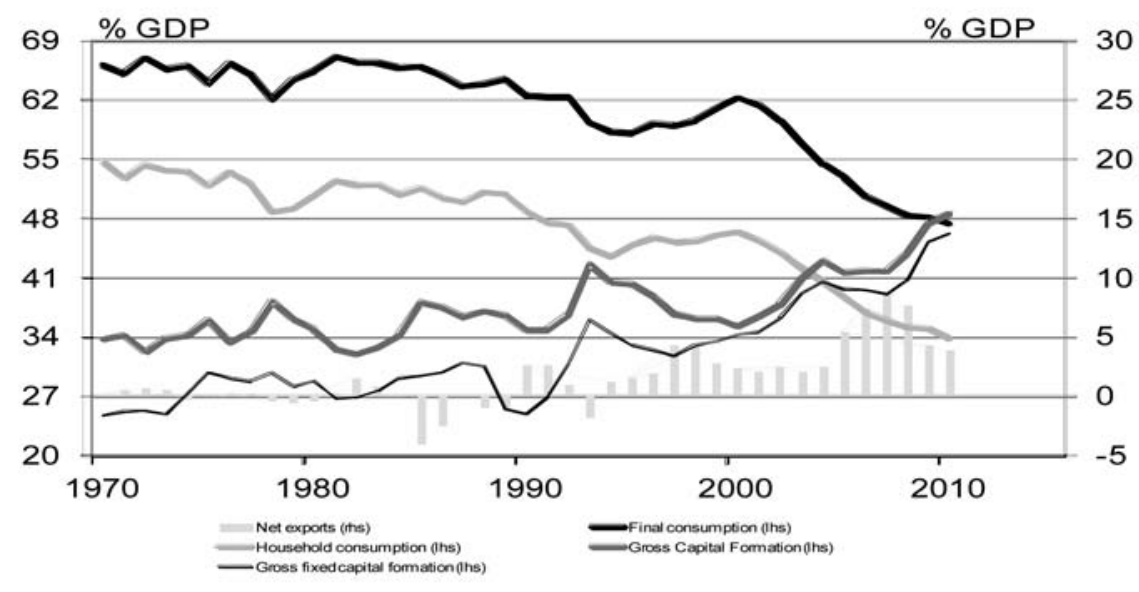

Source: CEIC data, available from <http://www.ceicdata.com/China.html> 
Figure 1.1 shows the composition of China's growth by broad expenditure measures of GDP from 1978 to 2010. Three broad trends are evident: from the late 1990s there was a sharp rise in the investment share of GDP and a sharp fall in the final and household consumption shares of GDP, while the share of net exports rose sharply from a modest base after 2002. China's high investment share of GDP implies a very rapid rate of capital accumulation. China's investment share of expenditure in GDP (using gross capital formation - that is, including inventories) rose sharply from 35 to 48 per cent of GDP between 2000 and 2010, equating to a 13 percentage point rise. ${ }^{1}$ A high investment share of expenditure in GDP is relatively common in industrialising economies, such as Japan in the 1960s and Korea in the 1970s, particularly in the early period of rapid (catch-up) economic growth (Fukumoto and Muto 2011; Knight and Wang 2011; McKay and Song 2010:Table 1, p. 6). Catch-up growth driven by rapid capital accumulation can be sustained for decades in capital-poor transitional economies with an abundant supply of labour. China's still relatively low level of income per capita and capital stock per worker, in addition to its relatively low (policy-suppressed) urbanisation rate and the relative backwardness of its central and interior provinces, argue that concentrated growth on the Chinese Mainland could potentially continue for longer than it did in its neighbours, including Chinese Taiwan and South Korea.

Nevertheless, China's investment-led growth model is coming under increasing scrutiny due to the increasingly unhelpful international environment in which it finds itself today, in addition to the sheer heft that China exercises as the world's largest manufacturing exporter, emitter and commodity consumer. Furthermore, the costs of resource-intensive growth-via high pollution and energy intensity - are becoming increasingly apparent. The low share of household consumption in total expenditure is a result of both a high marginal propensity to save and the low wage share of income at the national level (and declining real rural incomes). China has avoided a major slowdown or recession to date, but cyclical overinvestment in certain sectors has been a feature of each successive boom, especially during the recent heavy-industry and stimulusinfused housing and transport infrastructure booms of 2004-07 and 2009-10 (McKay 2011)

The sharp rise in the investment share of expenditure in China's GDP has been mirrored by a fall in the share of final consumption expenditure. Figure 1.2 shows the fall in final consumption expenditure has been led by a falling share of household consumption. Between 1979 and 2010 total household

1 Note that gross fixed capital formation (GFCF) has risen by slightly less than gross capital formation (GCF) over the equivalent period, which reflects a cyclical rise in inventories at the end point. A longer sample, comparing 2010 with 1994, shows that GCF rose by 8 percentage points of GDP but GFCF rose by 12 points. This reflects the fact that the increasing commercialisation and efficiency of the corporate sector have reduced the bloated inventory position that characterised the early transitional economy. 
consumption expenditure fell by 13 percentage points. This fall in the share of household consumption expenditure has been led by a fall in the share of rural household consumption, which has not been offset by urban consumption growth. Across this period, the government share was low and declined from 15 to 13 per cent of final expenditure. ${ }^{2}$ As a result, China's share of consumption expenditure remains at a relatively low level.

Figure 1.2 Final Consumption Expenditure Shares of China's GDP, 1978-2010 (per cent)

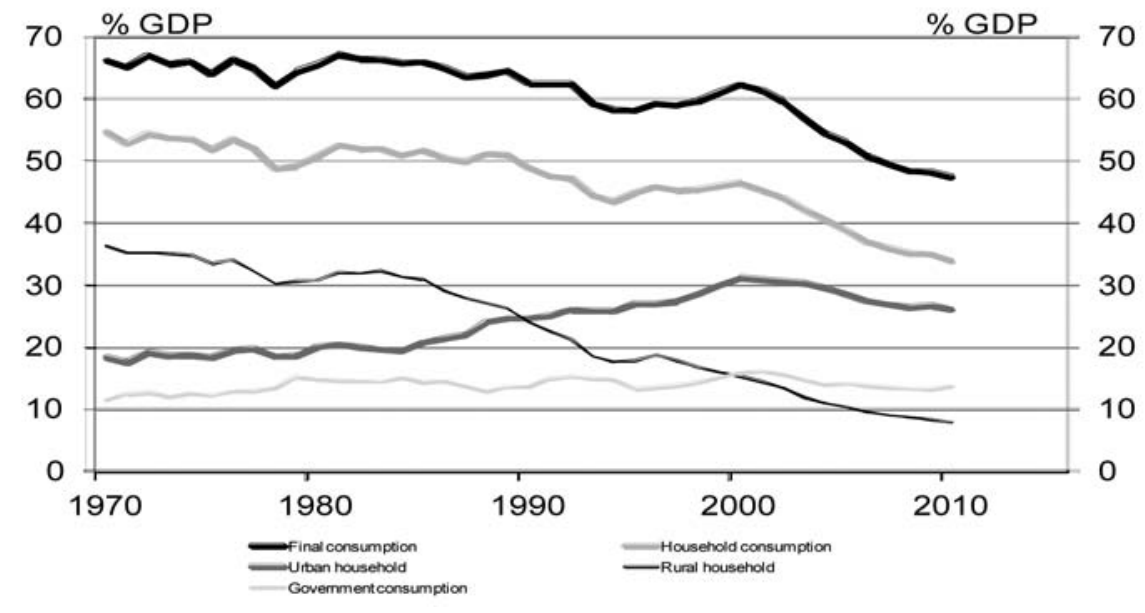

Source: CEIC data, available from <http://www.ceicdata.com/China.html>

The sharp rise in China's trade surplus between 2004 and 2008 was driven by a spectacular improvement in China's heavy machinery and transport balance, as documented by McKay and Song (2010) and shown in Figure 1.3. This offsets a widening deficit on primary products.

2 Note that the government share of income rose through this period, but the portion of public income allocated to capital formation rose, thus leaving public consumption at a low level. See the discussion of public savings in the chapter in this volume by Ma et al. 
Figure 1.3 China's Trade Balance, Decomposed by Broad Sector, 1993-2009 (per cent)

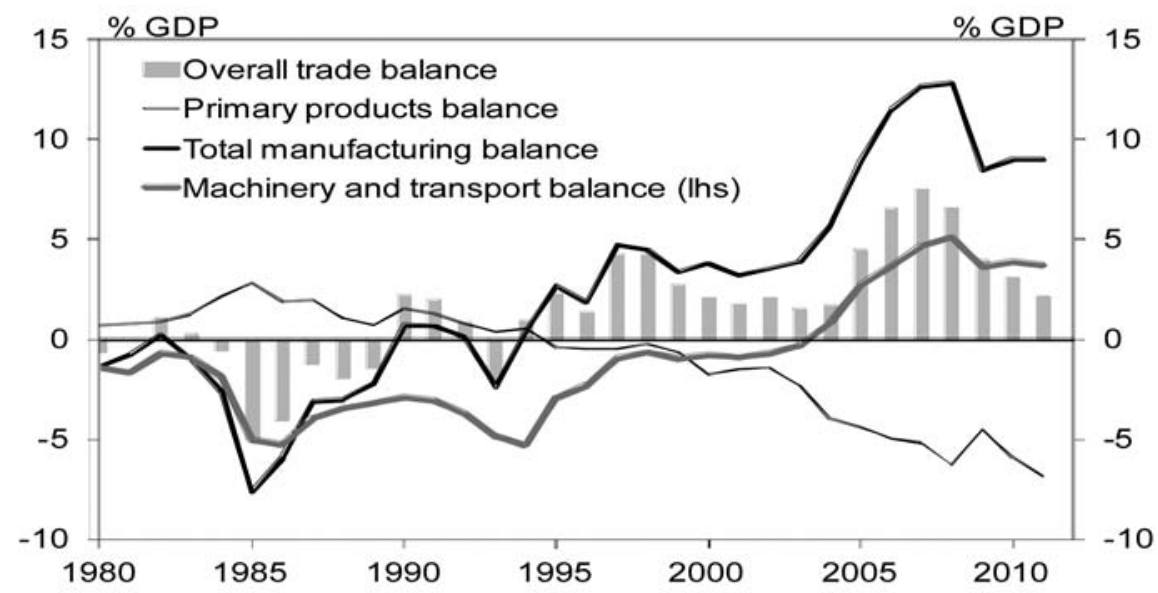

Note: Primary includes agriculture, fuel and other mineral resources.

Sources: CEIC data, available from <http://www.ceicdata.com/China.html> Updated data based on original in McKay and Song (2010).

China's total manufacturing trade balance was in net surplus from as early as 1994 but this was concentrated in lower value-added manufactures, and was initially offset by a net deficit in heavier machinery and transport sectors; however, the machinery and transport equipment balance turned to surplus and rose sharply from 2004 to 2008. This turnaround in the machinery and transport equipment balance was the result of rising investment in heavy industry in the early 2000s (Anderson 2008), which led to a sharp rise in heavy manufactured goods output, an expanding market share abroad and import substitution at home when capacity came on stream from 2004. Yet this sharp rise in output was not matched by an equivalent rise in domestic or foreign demand and, thus, the rise in market share led to falling prices, a lower rate of profit and continual deterioration of China's terms of trade (McKay and Song 2010).

Many of the challenges arising from China's structural imbalances are more or less common to transitional economies undergoing rapid growth and development. This is because the process of economic transition from a traditional to a modern economy entails a set of linked structural transformation processes such as industrialisation and urbanisation. This structural transformation is often marked by the concentrated growth of industry, a rising investment share, sharp rises in the energy intensity of production and demand for resources, and falling expenditure shares of consumption. 
Nevertheless, in the case of China's economy, the legacies of its pre-reform heavy industrial structure and its institutional and policy architecture have led to a pattern of growth marked by widening imbalances that are more pronounced than those seen in other industrialisation drives, and which were not present in the initial stages of China's reform. Indeed, China's pattern of growth during the 1980s was remarkably balanced by current standards as household incomes rose on the back of a rapid growth of labour-intensive production outside the traditional state-owned sector. China's domestic expenditure and external imbalances, however, widened in the 2000s as a result of China's stalled institutional reforms in the 1990s, and this has reinforced an investment-led industrial structure, especially in heavy industrial production and real estate development. The current growth pattern highlights the opportunity costs of stalled structural reform areas such as the migration and labour market systems, vertical fiscal relations, state-owned enterprises and the financial system.

Tackling China's economic imbalances requires economic policy reform to direct a new pattern of growth, which requires a major alteration of the current industrial structure and the institutional arrangements associated with it. The key is shifting the economic environment and incentive structure within which China's economic entities operate. The rebalancing policy objectives are to raise the domestic absorptive capacity of China's economy, through raising the relative share of consumption in final expenditure, rather than by seeking to reduce the net role of exports; and to direct resources further away from the relatively inefficient into the more productive sectors of the economy through an improved market mechanism.

Three sets of market-enhancing institutional reforms are necessary: reform of the labour system, reform of the financial system and reform of the government system, particularly in regards to the local government and state-owned enterprise sectors. The interdependence of the Chinese economy with the world economy also suggests the significance of these channels for international rebalancing (Deer and Song 2012).

The effective (as opposed to spatial) urbanisation of China's migrant workers is the most effective and realistic mid-term policy strategy for rebalancing China's macroeconomy. Institutional reform can accelerate the long-run processes of migration and urbanisation in China, which would raise domestic demand and, thus, reduce both the internal and the external imbalances in China's macroeconomy, and shift the current unbalanced industrial structure. A policy of urbanising rural migrant workers by removing threshold barriers 
to urban residency and ensuring equal access to social housing, education, health and social protection ${ }^{3}$ is likely to raise consumption by migrant workers (Song et al. 2010).

Moreover, the process of urbanisation requires investment in urban infrastructure (such as mass transit and utility provision) and in service industries. The effect, combined with higher domestic consumption by migrant workers, would be to raise growth and enhance structural change. Urbanising China's rural migrant workers would also help to integrate China's still segmented labour markets and provide a basis for long-term real wages to rise. Real wage gains can accelerate structural change by raising household consumption in domestic demand ${ }^{4}$ and by providing a basis for real currency appreciation. That can help shift China's industrial structure towards the tertiary sectors, which would benefit from the broader and deeper consumption basket of the better remunerated household sector. This would have positive implications for employment and enhance many qualitative aspects of future growth.

Given the objective of rebalancing China's industrial structure, capital market reforms are necessary for China to rebalance in three related areas: the allocation of capital, the cost of capital and the link between domestic financial reform and exchange arrangements. Although China's bank-dominated financial system deepened its asset base considerably over the reform period, China's system of formal credit allocation has remained narrow, and is mainly directed to the state sector as state-owned banks (SOBs) continue to dominate the sector. China's state-owned commercial banking sector allocates capital at rates that are low relative to those prevailing in private markets or a broad indicator such as the growth rate of nominal GDP, which reinforces the wider structure of investment and expenditure imbalances.

It will be difficult to develop domestic financial markets without further liberalisation of the foreign exchange system or of financial (capital) account controls. The two spheres are mutually reinforcing, even circular (McKay 2007). The exchange rate remains the anchor for China's monetary policy and any move towards a flexible currency needs to be accompanied by a shift to a different anchor. Current efforts to build up the interbank lending market and thereby establish a benchmark short-term interest rate to serve as this anchor show

3 Andrew Watson's chapter in this volume advocates a centralisation of the retirement income system - a recommendation in harmony with our own thinking.

4 Another way of thinking about this relation is through unit labour costs and the wage-profit share. If workers are under-remunerated for their productivity, unit labour costs fall and profits rise. That summarises the events of the past decade. Changing the direction of these dynamics - fully remunerating (or even a period of catch-up over remuneration) — would lower profits, boost the wage share, raise consumption and possibly lower investment also, although the effect on investment is ambiguous due to differentiated sectoral effects and the altered relative price between capital and labour predicted by rising unit labour costs. 
some promise. Speaking pragmatically, however, this market remains immature, liquidity remains variable and its ability to independently anchor monetary policy is a distant surmise. For now, all prescriptions for financial liberalisation must be offered within the context of the present regime apparatus.

A feasible reform would be to seek to incorporate China's large informal financial sector into the official financial system, in tandem with a removal of administrative ceilings on bank deposit rates and floor lending rates. The objective would be to create a legal sector of smaller non-bank financial lending and deposit institutions. ${ }^{5}$ These firms would compete with the banking system to provide market-based contract terms for households and small and medium- enterprises (SMEs). Once this reform has been given some time to gain traction, targeted moves to liberalise private capital outflows could be introduced as a further market discipline on the banking system. This would have the additional benefit of increasing the loan to deposit ratios of the banks, which would increase their wholesale funding requirements, which would deepen the interbank funding market, which would increase the potency of interest rates as a monetary policy tool, and thus accommodate the required transition away from the exchange rate anchor, as ventured above; however, the circularity of the financial reform arguments again come into play. The possibility of a deterioration of bank asset quality at a time of weak asset prices and a substantial pool of legacy loans from the quasi-fiscal lending expansion of recent years argues for a prudent approach to avoid unnecessary instability. Regardless of the precise time frame, deepening the reform of the SOBs is a requisite achievement if capital allocation is to improve and contribute positively to the ultimate rebalancing goal. Recent official commentary ${ }^{6}$ and the incorporation of interest rate liberalisation into the Twelfth Five-Year Plan offer some grounds for hope.

The current pattern of local government investment, especially its role in real estate investment, is a key element, along with the high share of investment in heavy industry, of China's cyclical macroeconomic imbalances, which have led to repeated overheating of China's economy during each phase of the investment-led boom (McKay 2011). Since fiscal reforms in 1994, the majority of government revenues have been collected by the Central Government, while local governments have remained responsible for the majority of public and social expenditure, especially on health and education (Figure 1.4). As a consequence

5 The recent rise of shadow banking in China indicates that this is not such a distant goal. Official data accessed via CEIC show that non-banks (and the off-balance-sheet activities of banks) made up 44 per cent of 'total social financing' in 2010, which is material. Indeed, the subsequent slowdown in non-bank finance is a major factor in the deceleration in economic activity under way in the first half of 2012.

6 Premier Wen Jiabao addressed the monopoly power of SOBs in a radio address in April, as reported in the Asian Wall Street Journal (2012). 
of this fiscal and governmental system, not only do local governments have a powerful incentive to maximise growth, but they also have an overriding fiscal incentive to do so through driving new investments, such as in real estate, in which they have direct or indirect claims to income, rather than through raising consumption.

Figure 1.4 Revenues and Outlays by Level of Government

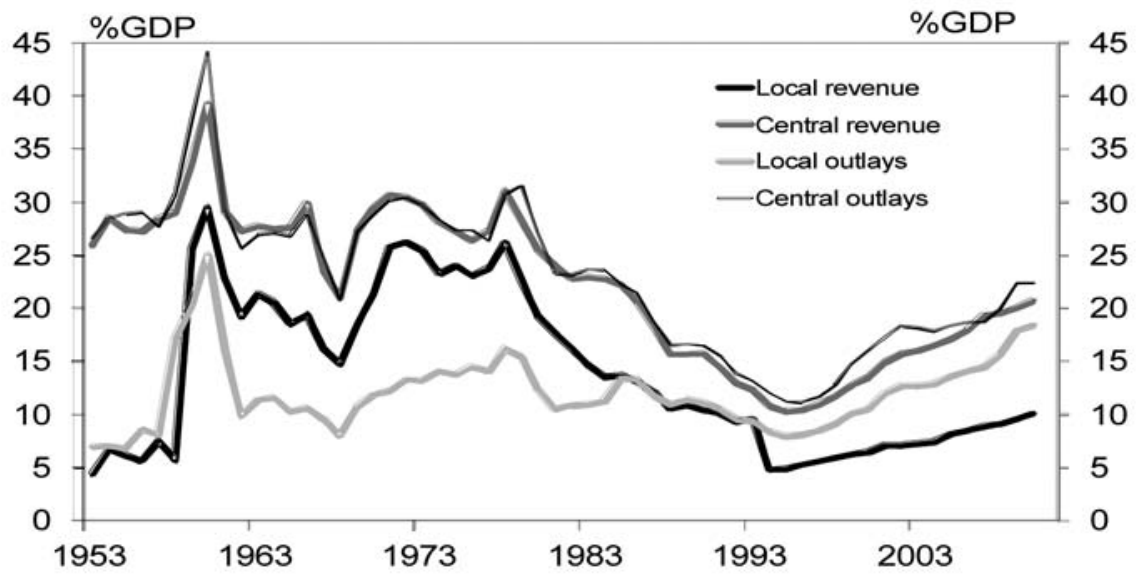

Sources: CEIC data, available from <http://www.ceicdata.com/China.html>

The current pattern of local government investment-and outlays, more broadly - could be better directed to meeting the needs of China's current urban and migrant populations by directing more expenditure to social housing and educational and social services (such as health, retirement income, transportation, unemployment insurance, public space and environmental amenity). There is much more to be done to reform the fiscal system at central and local government levels, including shifting the current land-transaction tax system to a property valuation and rates system. Reducing reliance on turnover and land sales would reduce two of the most egregious incentive distortions of the current system, while moving to a periodic valuation tax on housing would reduce investor willingness to leave property idle (untenanted), thus bringing about an effective increase in housing supply. Turning what is currently a heavily pro-cyclical revenue source (land sales) into something more closely resembling an annuity stream, would improve the sustainability of sub-national government finances in a material way. Recent moves to allow local governments to issue bonds, while cracking down on financing platforms, are useful policies but they do not attack the underlying issues. 
Rebalancing China's economy also requires reform of the state-owned enterprise (SOE) sector. There are immediate and long-term term reasons for this. Although China's SOEs no longer account for the majority of output in all sectors, the SOEs remain dominant in strategic monopoly sectors (Xiao et al. 2009). State-owned enterprises have accounted for much of the sharp rise in heavy industrial profits and enterprise savings in the period since 2000. The monopoly position of China's SOEs also poses a longer-term challenge to the reform of China's industrial structure towards a more balanced trajectory. Although the non-state sector accounted for the majority of industrial output in 2007, the SOEs accounted for more than 53 per cent of non-agricultural fixed investment, while employing only 13 per cent of the total workforce (Brandt and Zhu 2010). These discrepancies reflect the capital-intensive heavy industries in which the SOEs operate. They also suggest, however, an inefficient allocation of capital across sectors, which also reflects the still large distortions in China's factor markets, which cumulatively benefit the SOE sector disproportionately (Huang and Wang 2010). Rebalancing China's economy towards domestic demand will therefore require better access to capital for the non-state enterprises, reduced barriers to entry in SOE-dominated sectors, a greater openness to foreign direct investment in those same areas, further privatisation and a greater insistence on shareholder rights regarding dividend payments. The overall opportunity costs can be further reduced or even minimised should more resources be allowed to flow into the more vibrant non-state sectors through improved factor markets. This goal cannot be achieved unless China deepens the reform of state-owned enterprises.

Investment in hard infrastructure, from telecommunications to transport, remains central to long-term growth, but there is also a clear tendency towards cyclical overinvestment in certain heavy industries, from cement and steel production to machinery and transport production. Competition and anti-trust policy is needed to more fully redistribute monopoly rents (Tyers and Lu 2008), especially in China's strategic monopoly and pillar industries. Opening up share ownership and trading could potentially redistribute savings to a wider range of investors and allow new commercial entrants, while corporate tax reform through unifying the corporate tax rate for all firms including private and foreign firms could potentially redistribute more of these savings/profits to consumers. This suggests that the task of rebalancing will also hinge on how China reforms and strengthens its regulatory system especially with respect to competition, market entry and taxation.

High rates of investment at early stages of development tend to gradually shift towards a moderately rising consumption share as the structural processes of urbanisation and industrialisation effectively mature. The familiar inverted-U shape (sometimes labelled a Kuznets curve, as in McKay 2008) present across a 
number of development indicators when mapped in GDP per capita space attests to this. Therefore, it is entirely reasonable to expect China's domestic absorptive capacity to rise over time; however, while a rise in China's domestic absorptive capacity will, by definition, reduce China's external surplus, this does not mean that China's current account will move immediately into deficit; indeed, twin surpluses could remain for the time being. China's current account surplus has moderated in recent years on: a) soft demand for its exports; b) rapid increases in the price of its import basket; and c) strong demand for imported resource volumes. While an element of this narrowing is evidently cyclical, and thus we should not use the absolute latest level as the 'jumping off point', it is most unlikely that the current account will ever again approach the level seen in 2007. The rough estimate of Ma et al. (Chapter 4, this volume) that the average current account will move towards 1 per cent of GDP over the coming decade is a good starting point for discussion and debate.

In any case, the pressures that are currently building will ultimately convince China to accelerate the pace of structural adjustment including the pace of liberalising its capital account with the full convertibility and 'internationalisation' of the renminbi (RMB). At the same time, China's eventual success in achieving the objective of rebalancing will also depend on how China's major trading partners seek to overcome their own structural problems. The experiences of the United States show that while a deep recession can narrow external imbalances, mitigating the fallout from a contraction in private demand via fiscal expansion can substantially reduce policy flexibility down the line. The experiences of Europe show that ageing, developed economies with inflexible labour markets and exchange rates and open capital accounts can find the task of adjusting imbalances comes with major questions of financial instability and rising sovereign risks. The Japanese story is a cautionary tale that shows that sometimes even a sharp decline in the investment share will not bring about external rebalancing. The global economy will be challenged to maintain the rate of expansion required to return balance sheets to health while demand centres and relative prices continue to shift.

Tackling China's economic imbalances necessitates economic policy reform to facilitate a more sustainable pattern of growth that will fundamentally alter China's industrial structure and its trade orientation. Rebalancing requires a strategy for removing factor price and cost distortions that have arisen from the traditional state-owned heavy industrial and governmental structures and the macro-financial architecture that supports them.

Market-enhancing institutional reforms will be central to the reduction of China's macroeconomic imbalances. The next phase of transition must be built around a strategy of reforms in four key areas: the migration and labour market system, reform of the government system (particularly local government, with 
an emphasis on a sustainable fiscal policy and better decision making regarding outlays), reform of the state-dominated non-financial sectors and reform of the overall financial system. Each of these strategic areas constitutes a key link in the overall path-dependent chain that constitutes China's current and future structural trajectories. Reform in these segments will have strong positive multiplier and spillover effects in a range of sub-aggregate arenas relevant to achieving greater equity (contemporary and intergenerational), balance and sustainability.

\section{Structure of the Book}

We began by stating that 'the role of policy should be to design and implement a framework that reduces distortions, encourages and rewards innovation, equalises access to education, employment, a social safety net and capital for investment, while minimising rent-seeking opportunities'. Each of the chapters in this volume tackles the issue of rebalancing. Part one comprises those works that do so directly in a broad macroeconomic framework. Part two comprises those chapters that approach imbalance from a sectoral or sub-macro perspective.

Part one begins with a chapter by Rod Tyers that styles the rebalancing imperative as the search for inward-looking growth. To frame the discussion, Tyers presents a menu of policy regimes that seems promising with regards to achieving this end. These regimes are then 'tested' via a model of the Chinese economy that emphasises the oligopoly power of large firms.

Working from a sophisticated conception of the middle-income trap- the distinction is between the "natural" slowdown in the convergence process... and premature stagnation due to powerful vested interests' - Tyers finds that a successful turn inwards should incorporate a 'more ardent attack on oligopoly rent'. In what fashion? Tyers argues that policies of pure privatisation and industrial fragmentation offer less promise than either price regulation or foreign competition in services.

The chapter by Anders C. Johansson puts a strong case that financial repression is a root cause of both domestic and external imbalances in the Chinese economy. He argues that comprehensive financial reforms should be central to any concerted attempt to address imbalances, although he is at pains to highlight that due respect for correct sequencing must be taken into account. By discussing the apparent international and local symptoms of China's financially repressive policies in an integrated framework, Johansson builds up a convincing narrative that a multitude of superficially disparate issues can be fruitfully considered from this perspective. 
In Chapter 4, Guonan Ma, Robert McCauley and Lillie Lam build on their impressive recent output on China's savings rate. The focus of this effort is the current account surplus from a savings-investment perspective, with an exchange rate overlay. A masterful review of the state of play in these areas is followed by some educated prognostication on the future course of the savings and investment shares over the coming decade, in tandem with some observations on the historical trajectory of the real exchange rate compiled under various methodologies. The authors conclude that the current account surplus is likely to narrow further in coming years, with the savings shares declining by more than the investment share, and the quite considerable historical (and future) real appreciation of the RMB the authors envisage continuing to do its work.

Chapters 5 and 6 can be considered together. Yue Que, Fang Cai and Xiaobo Zhang argue in Chapter 5 that the 'flying geese' are moving inland as rising cost pressures on the coast drive them out. In Chapter 6, Miaojie Yu and Wei Tian offer a rich and highly disaggregated view of the 'DNA' of China's processing trade, where a great many of these 'flying geese' reside. Que et al. empirically demonstrate why the push away from the coast has occurred. They show that the proportion of manufacturing activity accounted for by the coastal provinces follows an inverted-U shape, with the benefits of agglomeration initially drawing capital out of the interior, before factor prices in these densely occupied regions reached a threshold level, which was the signal to go west. $\mathrm{Yu}$ and Tian offer an extremely comprehensive overview of the processing trade - who, what, where, how - mining a huge database the authors created through an innovative merger of transaction and firm-level trade information. They supplement the descriptive element of the chapter with an estimate of productivity growth in the processing sector, which they conclude is lower than that of firms conducting ordinary trade.

The final chapter in part one is by Bijun Wang. Wang poses the question of whether China's outward direct investment (ODI) can contribute positively to the rebalancing issue through improving the quality of growth. She argues that this is an unanswerable question without more detailed knowledge of the motivation for and style of the ODI decision. To gain this insight, Wang presents granular data on approved transactions, suitably cleansed, arriving at a taxonomy suitable for addressing the rebalancing. To Wang, if ODI is undertaken from a resource security perspective, it removes a bottleneck in the economy as it is presently constructed, but it could reduce the incentive to alter the growth model in fundamental ways. If ODI is undertaken to acquire strategic assets, the implications for rebalancing are more promising, with both direct and tacit influences working to enhance the quality of growth. Efficiency-seeking ODI, 
which has contributed very strongly to structural change over the course of Japan's development drive, is not yet seen as a major factor driving the ODI decisions of Chinese firms.

The last two chapters of part one reflect one of the hallmarks of this volume: the recognition that disaggregated data - whether from the firm, the province, the county or the single industry - are of tremendous value in understanding macroeconomic trends in China and should not be the sole domain of sectoral experts. The chapters of part two continue in this vein, with some fascinating information presented on the spatial aspect of inequality, migration decisions, rural population and intergenerational mobility. Some of these data come from official sources; some have been created by painstaking survey work.

The issue of income inequality has become a major focus of policymakers in recent times. This volume contributes to the debate from a number of angles. In addition to the studies in part one that touch on the inequality issue in a broad macroeconomic framework, our knowledge of the spatial aspect of income inequality in China - all the way down to county level - is greatly enhanced by the results detailed in Chapter 8 by Tsun Se Cheong and Yanrui Wu. Further, in Chapter 10, Jane Golley and Sherry Kong delve into The Australian National University's Rural-Urban Migration in China and Indonesia (RUMiCI) survey database to broaden our understanding of educational access (a fundamental driver of inequality) across generations and locales.

Cheong and Wu offer a comprehensive study of the spatial distribution of income inequality. Their work is distinctive as it estimates contributions to inequality across five spatial tiers, starting at the county level. They find that intra-provincial differences in output per head-that is, differential income levels across counties in the same province-are substantial contributors to overall inequality levels. They argue that this makes the case for policy formulation to have a strong local component. Further, they find that inequality has different spatial characteristics in the hinterland (where inter-county inequality dominates) and the coastal and north-eastern regions (where intercity inequality is an additional major factor).

Golley and Kong undertake a detailed study of intergenerational patterns of educational attainment across three population segments: urban residents, rural residents and rural-to-urban migrants. They begin with a multilayered question: 'Does the persistence of educational attainment across generations reflect genetic factors, uneven opportunities or uneven returns?' They approach the question by documenting evidence of the degree of persistence/mobility in intergenerational educational achievements in the above segments. They find that the uneven nature of returns to education in urban and rural areas, a lack of investment in rural education from early childhood onwards and 
the segmented urban labour market skew the incentives to pursue education, particularly beyond junior high; urban residents have a strong incentive to move up the ladder, rural residents less so, with migrants somewhere in between. This reinforces and amplifies the urban-rural divide.

Chapters 9 and 11 offer new perspectives on China's rural communities and the actual and potential internal migrants within them. In Chapter 9, Sylvie Démurger delivers some compelling insights into the complex economic and social calculus that goes into the migration decision: the decision to leave home, where (how far) one should go and for how long. Her framework, which owes much to the 'new economics of labour migration', takes the household as the basic decision-making unit and the household's goal is to minimise income risk. The boundaries of the investigation are set beyond economic, landholding and geographic factors to incorporate the influence of social and family networks. Social networks are shown to be a significant influence on migration decisions that send the individual far afield, whereas it is only the presence of a family network that is significant for shorter haul migration. Chapter 11 gives an initial glimpse of a new demographic survey undertaken in a number of key migration source regions in rural China, with data collected in the winter of 2010-11. Funing Zhong and Jing Xiang offer a discussion of their sample relative to that of the official household survey, detail their methodology and collection method and give some preliminary conclusions on the basic contours of the data. Expect to hear a great deal more from this project as time goes by.

One cannot get too deep into an educated discussion of Chinese imbalances without making mention of the social safety net. Yet detailed work on this vital policy area is surprisingly scarce. Chapter 12 by Andrew Watson steps into the breach, focusing predominantly on the provision of retirement incomes in an ageing society. Watson highlights the fact that the current system is contradictory, with a geographically fluid labour market sitting uneasily alongside a geographically rigid social security infrastructure. Following a magisterial account of historical developments and the current policy position, Watson recommends the adoption of an integrated, portable, centrally funded and administered system characterised by equal access for all citizens. This chapter is highly recommended to all those who have at some stage caught themselves vaguely recommending social security reform in China without any specific notion of exactly what that might entail.

The following chapter, by Zhiyun Zhao and Chaofeng Yang, looks at China's efforts to move up the value chain and become an internationally competitive innovator, which is an important co-requisite of travelling the positive road to a more balanced economy. At the outset, the authors characterise China's high-tech industry of today as being afflicted by weak innovation capacity, low technology intensity and poor economic efficiency. They posit that with 
developed countries pursuing a 'technology blockade' strategy, it is vital that China builds an indigenous innovation capability, with imported technology playing a complementary role. To them, this implies that a preferential industrial policy for firms with innovative potential should be put in place. They also offer a practical suggestion for policy design that will be swiftly recognised by those who stand by the maxim 'what gets measured gets done'. They argue that quantitative targets for high-tech output at the local level should be replaced with qualitative ones that emphasise the desire for more sophisticated production. Further, they argue that competition policy should be used to reduce entry barriers (with a side note that large firms in China are less innovative than smaller ones), the Government should play a guiding role while market forces should be catalytic, while noting an inherent institutional weakness in the commercialisation of innovative ideas.

The volume concludes with two chapters dealing with China's resource endowment. Chapter 15 deals with its quest for security of energy supply while Chapter 14 looks at its struggles to maintain the quality and abundance of its water supply. In Chapter 14, Hong Yang, Zhuoying Zhang and Minjun Shi offer a timely reminder that the joint problems of water pollution and water scarcity together threaten to undermine economic growth. They highlight the fact that China's industrial structure - which makes it a net exporter of virtual water (or embodied water) - is incompatible with its status as a water-poor country. They also go below the national level to highlight that the regional distribution of economic activity places water-intensive manufacturing in water-poor locales.

The energy security issue remains an emotive one inside China and without. ZhongXiang Zhang's chapter, which concludes the volume, aims to address what he feels are the 'misconceptions and misunderstandings' surrounding energy security in both China and internationally. Coincidentally, the East-West Centre in Hawaii, one of Zhang's academic homes, seems an ideal place from which to intermediate the sometimes strident discourse. Zhang makes a number of important points. The first is that for China, energy security is really about oil security. The second is that the Strait of Malacca is the major point of strategic vulnerability for China, given it has little geopolitical leverage in the area and the disproportionate amount of its imports using this narrow body of water. He ties this reality to the Chinese perception that an 'oil blockade' of China by the West is a genuine threat; and then douses the flames by systematically dismantling this thesis. Three, he emphasises that the loans-for-oil deals between Chinese development banks, foreign oil concerns and China's own national oil companies have not been successful in reducing energy insecurity, principally because the Chinese companies have shown no clear predilection to bring the 
oil home for domestic consumption where prices are set below those prevailing in international markets. Further, he argues that Chinese investment is adding to global supply potential in a net sense, which benefits all consumers of oil.

\section{References}

Anderson, J., 2008, 'China's industrial investment boom and the renminbi', in M. Goldstein and N. Lardy (eds), Debating China's Exchange Rate Policy, Peterson Institute for International Economics, Washington, DC, pp. 61-9.

Asian Wall Street Journal, 2012, 'Chinese premier blasts banks', Asian Wall Street Journal, 4 April, viewed 15 May, <http://online.wsj.com/article/SB100 01424052702304750404577321762422668428.html>

Brandt, L. and Zhu, X., 2010, Accounting for China's growth, IZA Discussion Paper No. 4764, Institute for the Study of Labour, Bonn.

Deer, L. and Song, L., 2012, 'China's approach to rebalancing: a conceptual and policy framework', China and World Economy, vol. 20, no. 1, pp. 1-26.

Fukumoto, T. and Muto, I., 2011, Rebalancing China's economic growth: some insights from Japan's experience, Bank of Japan Working Paper Series 2011 No. E-5, Bank of Japan, Tokyo.

Huang, Y. and Wang, B., 2010, 'Cost distortions and structural imbalances in China', China \& World Economy, vol. 18, no. 4, pp. 1-17.

Knight, J. and Wang, W., 2011, China's macroeconomic imbalances: causes and consequences, Bank of Finland Institute for Economies in Transition Discussion Papers No. 15, Bank of Finland, Helsinki.

McKay, H., 2007, 'Reforming China's exchange arrangements: monetary and financial sovereignty, sequencing and the foreign exchange market', in R. Garnaut and L. Song (eds), China: Linking markets for growth, Asia Pacific Press, Canberra, 290-315.

McKay, H., 2008, Metal intensity in comparative historical perspective: China, North Asia, the United States \& Kuznets curve, Global Dynamic Systems Centre Working Paper 006, The Australian National University, Canberra.

McKay, H., 2011, 'China's turbulent half-decade', in L. Song and J. Golley (eds), Rising China: Global challenges and opportunities, ANU E Press, Canberra, pp. 9-27. 
McKay, H. and Song, L., 2010, 'China as a global manufacturing powerhouse: strategic considerations and structural adjustment', China \& World Economy, vol. 18, no. 1, pp. 1-32.

Song, L., Wu, J. and Zhang, Y., 2010, 'Urbanisation of migrant workers and expansion of domestic demand', Social Sciences in China, vol. 31, no. 3, pp. 194-216.

Spence, M., 2011, The Next Convergence: The future of economic growth in a multispeed world, University of Western Australia Press, Perth.

Syrquin, M., 1988, 'Patterns of structural change', in H. Chenery and T. N. Srinivasan (eds), Handbook of Development Economics, North-Holland, Amsterdam, pp. 203-73.

Tyers, R. and Lu, F., 2008, 'Competition policy, corporate saving and China's current account surplus', Working Papers in Economics and Econometrics No. 496, College of Business and Economics, The Australian National University, July.

Xiao, G., Yang, X. and Janus, A., 2009, 'State-owned enterprises in China: reform dynamics and impacts', in R. Garnaut, L. Song and W. T. Woo (eds), China's New Place in a World in Crisis: Economic, geopolitical and environmental dimensions, ANU E Press, Brookings Institution Press and Social Sciences Academic Press, Canberra, pp. 155-78. 